\title{
Types of Interactive Methods in Teaching English to Students of Economics
}

\author{
Elena Eltanskaya \\ Department of Foreign Communication \\ Institute for Philology and Cross-Cultural Communication \\ Volgograd State University \\ Volgograd, Russia \\ yeltanskaya@volsu.ru \\ Yulia Linkova \\ Department of Foreign Communication \\ Institute for Philology and Cross-Cultural Communication \\ Volgograd State University \\ Volgograd, Russia \\ linkova@volsu.ru
}

\author{
Olga Popova \\ Department of Foreign Communication \\ Institute for Philology and Cross-Cultural Communication \\ Volgograd State University \\ Volgograd, Russia \\ popova@volsu.ru
}

\author{
Anastasia Arzhanovskaya \\ Department of Foreign Communication \\ Institute for Philology and Cross-Cultural Communication \\ Volgograd State University \\ Volgograd, Russia \\ arjanovskaya@ volsu.ru
}

\author{
Yulia Kulichenko \\ Department of Foreign Communication \\ Institute for Philology and Cross-Cultural Communication \\ Volgograd State University \\ Volgograd, Russia \\ kulichenko@volsu.ru
}

\begin{abstract}
Social and economic changes that have taken place in the country in recent years make new demands on specialists in various fields of knowledge, and economists are no exception. The English language study plays a major role in forming professional qualities of future economists. The implementation of the tasks requires the use of various methods in teaching English to students of economic departments, but the main methodological innovations today involve the use of interactive teaching methods. The article describes practical examples of using the most popular interactive teaching methods (role play, brainstorming, case study, discussion) at the English language classes with students of economic departments. The authors come to the conclusion that the use of interactive methods in teaching a foreign language to future economists helps to organize an active interaction of all participants of the communication process which results in the exchange of professional information in a foreign language and the acquisition of professional qualities and practical skills of business communication.
\end{abstract}

Keywords-interactive teaching methods; role play; brainstorming; case study; discussion; developing professional skills.

\section{INTRODUCTION}

The social and economic changes that have taken place in Russia and in the world over recent years have led to the new requirements for the specialists in different scientific fields, including economists. Nowadays the graduates in economics have to work under crisis conditions, analyse the current economic processes and find effective ways to solve the problems, possess leadership skills, be good at creative work and decision-making. The professional qualities of the students in economics are developed not only by professional disciplines. General subjects such as the foreign languages play an important role too [1].

In order to achieve these goals, foreign language teaching should include different methods; however, the main innovations are connected with the use of the interactive methods [2].

Interactive means that people work together and have an influence on each other. This situation implies dialogue or conversation. Therefore, these methods are aimed at the interaction between not only students and the teacher but also with each other, it requires an active role of students in the learning process [3]. The purpose of the interactive learning is to create the special conditions leading to the involvement of all students in the learning process when the participants can understand and realise everything that happens, influence each other and make their own contribution having established the friendly and mutually supportive relationship. Thanks to the use of the interactive learning methods the students in economics are taught to think critically, discuss, analyse the conditions and solve difficult problems related to their future 
professional activity, evaluate opposite opinions, make informed decisions, etc. [4].

\section{Role Plays}

Some interactive techniques are described in the academic literature. The most popular methods are role plays, brainstorming, case study method, presentations and discussions. They develop communicative skills, logical thinking and different types of intellectual activity such as analysis, synthesis, comparison, and generalisation [5]. These student-centred methods are highly appropriate, particularly for involving students more actively in acquiring knowledge, skills and strategies [6].

In this article, the authors are going to give some examples of the use of these techniques for teaching English as a foreign language to the students of Volgograd State University.

\section{A. The aim of role plays}

It is commonly known that role plays make the learning process at the university more educational and proficient, improve interdisciplinary relationships, connect the theory with real needs of the professional field, and develop skills that are necessary for the future specialists. The key element is the role playing that gives opportunity to form skills that are difficult to acquire under ordinary learning conditions [7]. Since business simulation is the form of creation of the professional activity and modelling its typical relationships it allows developing conditions necessary for training the future specialist that are more adequate and effective in comparison with traditional learning process.

\section{B. The Presentation of the Hotel Project}

At the English lessons at Volgograd State University, the authors have used a number of role plays developing the professional qualities of the future economists. As an example, the authors would like to analyse the method of role play that is called The Presentation of the Hotel Project. They have used this type of learning activity with the students of the Institute of World Economy and Finance.

According to the game plan, the students are divided into two groups. The task of the first team is to develop a model of the future hotel and make a presentation of their hotel project to the second team of the students playing parts of the bankers financing this project. The aim of the presentation is to persuade the funders of the investment prospects of the project.

In addition to the card with the formulation of the assignment, the students of the first subgroup are offered additional questions about the projected hotel complex, which will become a linguistic and informative support for their future performance. Learning on this auxiliary material, the students of the first subgroup collectively develop the model of the hotel complex, distribute key moments of the presentation, think through its structure, decide with what language tools it is possible to make their speech as convincing as possible. Before a rehearsal of the performance, the group elects the leader of the presentation who takes the responsibility for representation of all participants of the presentation and informing audience on the presentation course.

It is supposed that at an early stage of preparation for holding a business game students have studied recommendations about the organization of the group presentation, having received distributing material. Students of the second subgroup, playing the role of bankers, are the audience of this presentation. Their task is to think through the questions to the speakers in order to be convinced of the reliability and profitability of the submitted project.

It is assumed that some students will prepare some of the questions in advance, and a number of questions will arise during the presentation, which will require the students to have active listening skills.

Prior to the start of the game, the teacher informs students about the criteria for assessing their oral performances and warns that the game will be recorded on a digital video recorder so pupils could estimate extent of achievement of communicative competence of each participant of the game, and also the general course of the presentation [8]. At the end of the game, a video recording, a collective discussion of the results and a joint summing up are carried out.

The analysis of games in a foreign language showed that students having entered the role, overcame the language barrier, did not hesitate to express their thoughts in a foreign language, showed creativity and independence of thinking. Despite of the presence of some language errors, the communication was lively and emotional. The students demonstrated good knowledge and skills in their specialty and tried to realize their professionally significant qualities as much as possible.

\section{BRAINSTORMING}

Another interesting interactive method that allows forming professionally significant qualities of future economists and developing their economic thinking is brainstorming. Brainstorming represents joint search of the ideas necessary for the solution of any problem. The main advantages of this method (on condition of its correct application) are that students seem to be "liberated" - the language barrier disappears, there is no fear to say something wrong, the restraint goes away, etc. The method of brainstorming develops creative and associative thinking, initiative, the ability to produce a maximum of ideas in a tight time, the ability to express personal opinion [9]. The method of "brainstorming" differs from the discussion one in that it implies the rejection of any criticism of ideas [10]. The following can be offered as subjects for "brainstorming" students-economists:

- What is the secret of IKEA?

- What business would you open?

- What are the best ways of advertising of a new model of a cell phone?

- Would you like to live in a traditional economy? 
- What new marketing technologies do you know?

\section{CASE-STUdY}

An equally interesting interactive method that a foreign language teacher can use when teaching students in economic specialties is the case-study method. Its main goal is to teach future specialists to analyze information, evaluate alternative ways of solving the problem and find the most optimal option out of several possible ones [11].

The following situation may be an example: Hudson, an American company producing high quality suitcases and travel bags engages in severe competition with Asian companies selling the same products at much lower prices. Hudson's market share is plummeting. The company board decides to expand operations and enter the European market. The corporation management is developing appropriate marketing strategies. Students get into groups and act as Hudson Corporation's CEOs. They receive four detailed strategies, examine them carefully, and then hold a meeting discussing the benefits and drawbacks of each marketing strategy within the group. Then the students join up into a single group and make the final resolution as to which two of the marketing vehicles shall be employed to expand the European sales [12;13].

As exemplified by the above situation, the advantage of the method in question is the ability to develop skills of team work, interdisciplinary awareness, context analysis, choice estimation, and also abilities to present the results of conducted research and to project the consequences of one's resolution.

\section{DISCUSSION PRACTISE}

Another important interactive method to be employed for teaching English as a foreign language to the students of economics is a discussion practice. Taking part in a discussion is a professionally significant communication situation for economists, still more it demands higher language proficiency and a certain achieved level of professional knowledge, so it is advisable to set up such discussions at final stages of a vocabulary topic study [14]. Generally, the discussion is started by the teacher who is setting forth a controversial issue. For instance, after the "Types of Business Associations" topic is studied, one may offer the students to discuss which organizational form is better, assuming that the participants will be actively arguing on the benefits and drawbacks of private enterprises, partnerships and public companies while giving pro and contra arguments. Note, that for adequate discussion process the teacher must provide conventional phrases of business communication expressing various intentions, e.g. those regulating discussion process ("Shall we get started?" etc), statement arrangement ("There are several points I'd like to make"), expressing confidence or doubt, or agreement ("I'm sure that..." / "It seems to me that..." / "I agree to the point") etc. Group discussion practices ensure topic consolidation and give extra cross-disciplinary opportunities [15].
Thus, it should be noted that interactive methods in teaching English as a foreign language to the students of economics ensure energetic interaction of communication parties. This results in active exchange of professionally significant information in foreign language, cultivates both professional and business communication skills.

Analysis of questionnaire results shows that all students deem interactive methods helpful in English studies, because these methods enliven the process, help to overcome stage fright, promote professional skills development, and benefit communications in the native language of students.

\section{References}

[1] S.B.Stupina, "Technologies of interactive learning in higher education: the teaching method," allowance, Saratov: Science, 2009.

[2] Continuity in foreign-language education: problems and prospects: monograph, E.A. Isakovich, and N.N. Kolobkova, Eds. Volgograd, Volgograd scientific publishing house, 2016, pp. 123-133.

[3] E.V. Kaminskaya, "A variety of modern interactive methods of teaching a foreign language in a university," Language and the world of the language, No. 7, pp. 159-165, 2016.

[4] O.V. Zhironkina, "Interactive methods of teaching foreign language to future economists in class," Bulletin of KemSU, No. 1, pp. 37-45, 2009.

[5] Yu.N. Kulichenko, O.Yu. Popova., Yu.I. Linkova, "The use of multimedia presentations in teaching a foreign language to students of non-llanguage specializations," The world of science, culture, education, No. 4 (59), pp. 30-33, 2016.

[6] P. Westwood, "What teachers need to know about teaching methods". Camberwell, Vic.: ACER Press, 2008, 105 p.

[7] M.A. Suzdalova,V.G. Lizunkov, E.Yu. Malushko, N.A. Sytina, V.E. Medvedev, "Innovative Forms of Partnership in Development and Implementation of University-Business Cooperation," "The European Proceedings of Social \& Behavioural Sciences EpSBS”. vol. XIX. 2017, Article \#61. Pp. 450-455.

[8] V.G. Lizunkov, M.G. Minin, E.Y. Malushko, V.E. Medvedev, "Developing economic and managerial competencies of bachelors in mechanical engineering," "SHS Web of Conferences", vol. 28, 2016. Article \#01063.

[9] S.V. Kuznetsova, E.V. Shepeleva, "The method of "brainstorming" in teaching English to university students," Pedagogy and Modernity, vol. 1, No. 1-1, pp. 72-76, 2014.

[10] Yu.A Sannikova, "The practice of applying a "brainstorm" in English lessons for students of non-linguistic specialties," Uchenye zapiski universiteta im. P.F. Lesgaft, No. 8 (138), pp. 186-188, 2016.

[11] A.D Efimova., G.N. Sleptsova, "Role games as a means of developing foreign-language business communication among students of nonlinguistic universities", in The Amur Scientific Herald. Komsomolsk-onAmur, Amur Humanitarian-Pedagogical University, No. 2, pp. 80-86, 2007.

[12] O.Yu. Popova, "The use of the case study method in teaching foreign language presenting skills to students of economic specialties", in Communicative aspects of modern linguistics and linguodidactics: materials of the Russian Scientific Conference, Volgograd, February 5, 2014. Volgograd, VolSU Publishing House, 2014, pp.106-109.

[13] L.V. Pokushalova, "Method of case-study as a modern technology of professionally-oriented training students", in Young Scientist, No. 5, vol. 2, pp.155-157, 2011.

[14] O.V. Grigorashm, A.I Trubilin, "Interactive methods of teaching in a modern university," Polymathematical network electronic scientific journal KubGAU, No. 101 (07), pp. 1286-1302,2014.

[15] A.V Schekoldina, "Formation of foreign-language discussion skills as a component of interactive competence among students of non-linguistic universities (on the basis of English language)," candidate's thesis in Pedagogical Science. Volgograd, 2005, 182 p. (in Russian). 